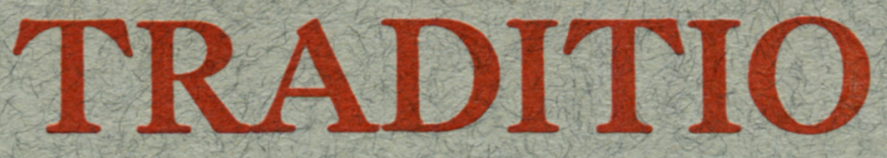

STUDIES IN ANCIENT AND MEDIEVAL HISTORY, THOUGHT, AND RELIGION

\author{
Editors \\ R. E. KASKE CHARLES H. LOHR \\ RICHARD E. DOYLE ELIZABETH A. R, BROWN \\ BRIAN E. DALEY \\ Editor Emeritus \\ STEPHAN KUTTNER
}

\title{
VOLUME XLI
}

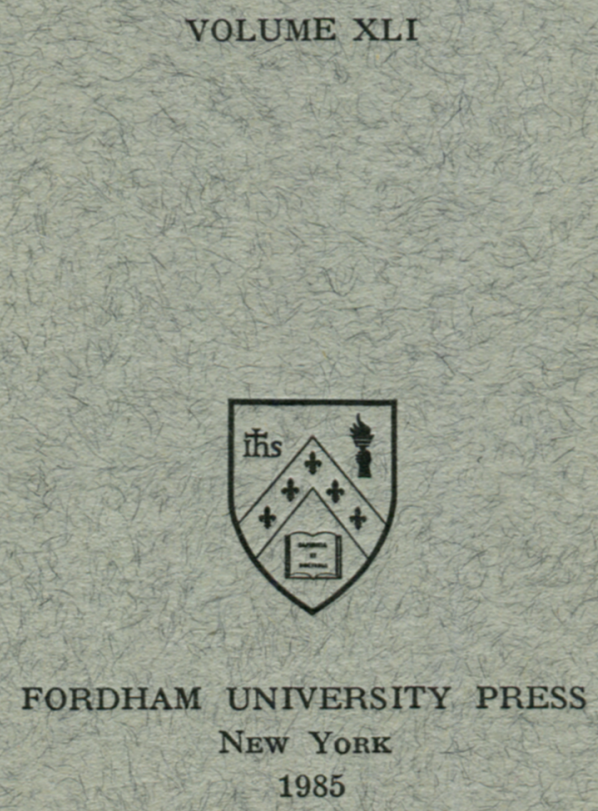




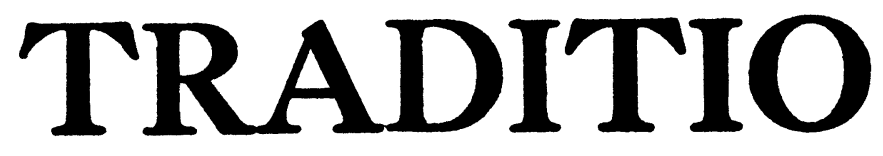

\title{
STUDIES IN ANCIENT AND MEDIEVAL HISTORY, THOUGHT, AND RELIGION
}

\author{
Editors \\ R. E. KASKE CHARLES H. LOHR \\ RICHARD E. DOYLE ELIZABETH A. R. BROWN \\ BRIAN E. DALEY \\ Editor Emeritus \\ STEPHAN KUTTNER
}

VOLUME XLI

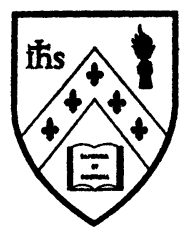

FORDHAM UNIVERSITY PRESS

New YORK

1985 


\section{TRADITIO}

STUDIES IN ANCIENT AND MEDIEVAL

HISTORY, THOUGHT, AND RELIGION

VOLUME XLI 


\section{CONTENTS}

\section{Articles}

Theurgy: Rituals of Unification in the Neoplatonism of Iamblichus

Gregory Shaw 1

'Vocans temporales, faciens aeternos': St. Augustine on Liberation from

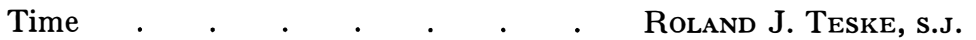

The Career of Venantius Fortunatus . . . Brian Brennan

The Latin and Old English Glosses in the Blickling and Regius Psalters

Phillip Pulsiano

Traditional Exegesis and the Question of Guilt in the Old English Genesis $B$

Susan Burchmore

Fourteen Charters of Robert I of Dreux (1152-1188)

Andrew W. Lewis

The Medieval Allegorization of the Aeneid: MS Cambridge, Peterhouse 158

Christopher Baswell 181

Abbot Suger and the Nuns of Argenteuil

Thomas G. Waldman

239

Olivi, Apocalyptic Expectation, and Visionary Experience

DAvid BURR

The Authorship of the Northern Homily Cycle: The Liturgical Affiliation of the Sunday Gospel Pericopes as a Test Thomas J. Heffernan

Literary and Philosophical Perspectives on the Wheel of the Five Senses in Longthorpe Tower

Gino Casagrande and Christopher KLeinhenz

\section{Miscellany}

The Two Redactions of Michael Scot's Liber introductorius

GLenN M. Edwards

\section{Bibliographical Studies}

A Guide to the Medical Manuscripts Mentioned in Kristeller's Iter Italicum III . $\quad . \quad$. $\quad . \quad$. $\quad . \quad$. Richard J. Durling

Census and Bibliography of Medieval Manuscripts Containing Apocalypse Illustrations, ca. 800-1500 (II) 


\section{ABBREVIATIONS}

The following sigla are used without further explanation:

\begin{tabular}{|c|c|}
\hline $\mathbf{A H}$ & Analecta hymnica medii aevi \\
\hline AS & Acta sanctorum \\
\hline CAH & Cambridge Ancient History \\
\hline CCL & Corpus Christianorum: Series latina \\
\hline CIL & Corpus inscriptionum latinarum \\
\hline CMH & Cambridge Medieval History \\
\hline CSco & Corpus scriptorum christianorum orientalium \\
\hline CSEL & Corpus scriptorum ecclesiasticorum latinorum \\
\hline DACL & Dictionnaire d'archéologie chrétienne et de liturgie \\
\hline DDC & Dictionnaire de droit canonique \\
\hline DHGE & Dictionnaire d'histoire et de géographie ecclésiastiques \\
\hline DS & Daremberg-Saglio, Dictionnaire des antiquités grecques et romaines \\
\hline DThC & Dictionnaire de theologie catholique \\
\hline Du Cange & Du Cange, Favre, Henschel, Glossarium mediae et infimae latinitatis \\
\hline EETS & Early English Text Society \\
\hline GCS & Die griechischen christlichen Schriftsteller der ersten drei Jahrhunderte \\
\hline HBS & Henry Bradshaw Society \\
\hline IG & Inscriptiones graecae \\
\hline ILS & Dessau, Inscriptiones latinae selectae \\
\hline $\begin{array}{l}\text { JL } \\
\text { JK } \\
\text { JE }\end{array}$ & $\begin{array}{l}\text { Jaffé, Regesta pontificum romanorum ... ed. secundam curaverunt } \\
\text { S. Loewenfeld (JL: an. 882-1198), F. Kaltenbrunner (JK: an. ?-590), } \\
\text { P. Ewald (JE: an. 590-882) }\end{array}$ \\
\hline LThK & Lexikon für Theologie und Kirche \\
\hline Mansi & Mansi, Sacrorum conciliorum nova et amplissima collectio \\
\hline MGH & Monumenta Germaniae historica \\
\hline PG & Migne, Patrologia graeca \\
\hline PL & Migne, Patrologia latina \\
\hline PO & Patrologia orientalis \\
\hline Potthast & Potthast, Regesta pontificum romanorum \\
\hline RE & $\begin{array}{l}\text { Pauly, Wissowa, Kroll, Real-Encyclopädie der klassischen Altertums- } \\
\text { wissenschaft }\end{array}$ \\
\hline $\mathbf{R I S}^{2}$ & $\begin{array}{l}\text { Muratori, Rerum italicarum scriptores: Raccolta degli storici italiani, nuova } \\
\text { ed. . . con la direzione di G. Carducci, V. Fiorini, P. Fedele }\end{array}$ \\
\hline SIG & Dittenberger, Sylloge inscriptionum graecarum \\
\hline ThLL & Thesaurus linguae latinae \\
\hline TU & Texte und Untersuchungen zur Geschichte der altchristlichen Literatur. \\
\hline
\end{tabular}

For serial publications of the great academies:

Abh. Akad. . . [ [followed by name of city, e.g. Berlin, Munich, etc.] = Abhandlungen der ... [preussischen, bayerischen, etc.] Akademie der Wissenschaften, philosophisch-historische Klasse.

Similarly for Mémoires, Memorie, Proceedings, Rendiconti, Sitzungsberichte, etc., the abridged form is always understood as referring to the series covering philosophy and the humanities where several classes or sections exist in a single academy E.g.:

Mem Acad. Inscr.

Proc. Brit. Acad.

Rendic. Accad. Lincei
Rendic. Instit. Lombardo

Sb. Akad. Vienna 